\title{
The impact of coping strategies on the intensity of stress on hemato-oncology nurses
}

\author{
O impacto das estratégias de enfrentamento na intensidade \\ de estresse de enfermeiras de hemato-oncologia \\ El impacto de las estrategias de afrontamiento en la intensidad \\ de estrés de enfermeras hematooncológicas
}

\author{
Juliane Umann ${ }^{a}$ \\ Rodrigo Marques da Silva ${ }^{b}$ \\ Sonia Betzabeth Ticona Benavente ${ }^{c}$ \\ Laura de Azevedo Guido ${ }^{d}$
}

DOl: $\quad$ http://dx.doi.org/10.1590/1983-

1447.2014.03.44642

\footnotetext{
a Masters Degree in Nursing. Doctorate from the Federal University of Rio Grande do Sul (UFRGS), Porto Alegre, Rio Grande do Sul, Brazil.

${ }^{b}$ Masters Degree in Nursing. Professor of the Juinense Association for Higher Education (AJES), Juína, Mato Grosso, Brazil.

c Masters Degree in Nursing. Doctorate in nursing from the School of Nursing, University of Sao Paulo, Sao Paulo, Brazil.

d Doctorate in Nursing, Associate Professor (retired) of the Nursing Department of the Federal University of Santa Maria, Santa Maria, Rio Grande do Sul, Brazil.
}

\begin{abstract}
We intended to evaluate the impact of coping strategies on the intensity of stress on hemato-oncology nurses, using a transversal analytical study conducted with 18 nurses between March and April of 2010. We used a form for socio-demographic characterization, the Occupational Coping Scale to evaluate the coping strategies and the Nurses Stress Inventory to evaluate the stress. There was no significant correlation between coping strategies and stress intensity, however, in the dispersion analysis, the use of control and avoidance strategies increased stress intensity while the use of symptoms management decreased its intensity. Nurses with less time working in the health institution and those without a postgraduate degree presented higher stress intensity. We concluded that Symptoms Management strategy has a positive effect on the stress of hemato-oncological nurses, where the reduced perspective of healing and the chronic condition of the patients are inherent to the nursing work and make proactive and avoidance actions difficult. Descriptors: Nursing. Oncology nursing. Stress, psychological. Occupational health.
\end{abstract}

\section{RESUMO}

Objetivou-se avaliar o impacto das estratégias de enfrentamento na intensidade de estresse dos enfermeiros de hemato-oncologia. Estudo transversal analítico realizado com 18 enfermeiras entre março e abril de 2010. Aplicou-se um formulário para caracterização sociodemográfica, a Escala de Coping Ocupacional para as estratégias de enfrentamento e o Inventário de Estresse em Enfermeiros para avaliação do estresse. Para análise dos dados, utilizou-se o Teste de Correlação de Pearson e regressão linear. Não houve correlação significativa entre as estratégias de enfrentamento e a intensidade de estresse. Contudo, na análise de dispersão, o uso das estratégias de Esquiva e Controle elevaram a intensidade de estresse e uso do Manejo de Sintomas minimizou sua intensidade. 0 menor tempo de trabalho na instituição e ter pós-graduação implicaram em maior estresse. Conclui-se que a estratégia Manejo de Sintomas tem impacto positivo sobre o estresse dos enfermeiros de hemato-oncologia uma vez que é efetiva para minimizá-lo neste setor de trabalho hospitalar, onde a reduzida perspectiva de cura e a cronicidade dos pacientes são inerentes ao trabalho e dificultam ações proativas e de evitação.

Descritores: Enfermagem. Enfermagem oncológica. Estresse psicológico. Saúde do trabalhador.

\section{RESUMEN}

Intentamos evaluar el impacto de las estrategias de afrontamiento en la intensidad de estrés de las enfermeras de hematoncológicas. Estudio transversal analítico realizado con 18 enfermeras entre marzo y abril de 2010. Aplicamos un formulario para caracterización sociodemográfica, la Escala de Coping Ocupacional para evaluar las estrategias de enfrentamiento y el Inventario de Estrés en Enfermeros para evaluar el estrés. No hubo correlación entre estrategias de afrontamiento e intensidad de estrés, pero, en el análisis de dispersión, utilizar estrategias de Esquiva y Control aumentó la intensidad del estrés y utilizar el Manejo de los Síntomas redujo su intensidad. Trabajar menos tiempo en la institución y no tener posgrado llevaron a más estrés. Se concluyó que la estrategia Manejo de Síntomas tiene efecto positivo sobre el estrés de los enfermeros que actúan en hematooncología, donde la reducida perspectiva de cura y la cronicidad de los pacientes son inherentes al trabajo y dificultan acciones proactivas y de evitación. Descriptores: Enfermería. Enfermería oncológica. Estrés psicológico. Salud laboral. 


\section{口INTRODUCTION}

Infirmary care in the area of hematoma-oncology is complex and demanding due to the characteristics of this specialty, which include: long and aggressive treatments with collateral effects; mutilating surgeries; suffering and fear, feelings of desperation and panic from the patients and death. These aspects have been confirmed as stressors and are associated with psychological suffering in the nursing professional in oncology ${ }^{(1)}$.

Furthermore the hemato-oncology nurse faces difficulties in their everyday work related to, inadequate physical infrastructure, the everyday life of the patient with their family, and a lack of preparation and professional recognition, all have been identified as a cause of stress on the professionals and lead to occupational stress in oncology ${ }^{(2-4)}$.

Occupational stress refers to stimuli in the work environment, the so called organizational stressors, the responses (psychological, physiological and behavioral) of individuals who face these stressors and to the stressor-response process ${ }^{(5)}$. In this manner, the phenomenon can be defined by the interaction of work conditions with worker characteristics, in which the work demands exceed the individual's ability to cope with them(6).

In this way, investigations into occupational stress in oncology nurses have been conducted and the results show that the stressors are related mainly to organizational aspects, work conditions ${ }^{(1,7)}$, relationship with the patients and the terminal aspect ${ }^{(2-4)}$ of the illness. So we have learnt that there are some peculiarities inherent in the work of the hemato-oncology nurse which influence occupational stress and the process of coping, mediating between the evaluation and repercussion of the stressor for the individual.

Coping presupposes that there is the mobilization of resources so that the individual, through cognitive and behavioral effort, can manage the internal and external demands originating from his interaction with the environment, evaluated as a threat and exceeding the individual's capacity to confront them ${ }^{(8)}$. To deal with his occupational stress, oncology nurses can use strategies focused on the problem, indicating direct action (confrontation, control, social support) or actions focused on the emotional side, characterized by removal or inhibition of the action in relation to the stressor (distancing, denial, avoidance-escape) $)^{(1,4,7)}$.

Usually, the response to a specific stressor can be the utilization, combined and interdependent, of these types of coping strategies. This way, a coping strategy focused on the emotional side can help the coping strategy focused in the problem by easing the tension and equally the coping strategy focused on the problem can minimize the threat, so reducing the emotional tension ${ }^{(8)}$.

Based on the variety of situations that can be assessed by the nurses as stressors in their work environment and the coping strategies possible in this process, the complexity present in the work of a hemato-oncology nurse is highlighted.

As we recognize the risks attached to the response-stressor process mismatch, such as lack of concentration and work accidents, the frequency which they occur and the variety of coping options of the oncology nurses, it's believed to be possible, from recognition of the cause-effect relationship, to increase the coping resources for these professionals. On this subject, researchers have already analyzed the coping strategies and the stress intensity of nurses who worked in different hospital units ${ }^{(4,9-10)}$. However, very few have analyzed the impact of the strategies on the intensity of the stress on the nurses, especially the ones on hemato-oncology units.

In this perspective, it is considered that, with knowledge about coping strategies, principally of their effect on the individual in relation to a specific context, it becomes possible to raise the internal and/or external resources available and improve the individual's ability to face situations, considering the illness as well as their own personal needs.

From the above, the objective was to verify the impact of coping strategies on the intensity of stress on hemato-oncology nurses.

\section{METHODS}

A transversal analytical study developed in the hemato-oncology units of a University Hospital in Rio Grande do Sul, Brazil.

Permanently employed public healthcare nurses were included in the study, which were caring for the patients directly. It excluded professionals on leave for any reason during the collection of data. Since all the nurses who worked at the unit during the collection period fulfilled the eligibility criteria proposed, 18 nurses agreed to take part in the research and signed an Informed Consent Form.

The data was collected between March and April of 2010. For this, the nurses were contacted in team meetings when the study proposal and the invitation to take part were presented to them. This first contact was previously agreed between the researcher and the hospital unit coordinators. 
The protocol for the research involved the use of a form to socio demographically characterizes the subjects, using the Nurses Stress Inventory (NSI) and the Occupational Coping Scale (OCS). These instruments were delivered to the individuals and were filled in outside the work environment and they were returned by agreed appointment with the researchers, according to the availability of each professional.

The form for socio-demographic characterization featured the following variables: age, time working in the institution, time working in the unit, presence and absence rates, post-graduation.

The NSI, established and validated in Brazil in 2000, allows us to measure the general occupational stress of the nurse ${ }^{(6)}$. It is a self-administrated instrument, consisting of 38 items using the Likert five point scale where: 1 point is "never", 2 points is "rarely", 3 points "sometimes", 4 points is "many times" and 5 point is "always". This way the points given to each item refer to the frequency that the stressors are experienced by the nurse in their everyday work. These items are distributed into three domains, as follows: Interpersonal Relationship (Items : 2, 3, 11, 13, 19, 20, 21, $22,23,24,25,27,28,33,35,37,38)$, Roles of Stressors within Careers ( items 15, 16, 17, 18, 26, 29, 30, 31, 32, 34, 36), and Intrinsic factors at Work (items 1, 4, 5, 6, 7, 8, 9, 10, $12,14)^{(6)}$. In the first domain, Interpersonal relationships in the work environment are addressed, for example, relationships with other healthcare professionals, patients and their family, students and the nurses own family. The second domain refers to questions related to a lack of understanding, autonomy, professional uncertainty, powerlessness when faced with certain situations, physical environment aspects and the institutional organization. In the last domain, the functions of work performance are addressed, such as working shifts and adequacy of resources ${ }^{(6)}$.

The OCS was translated, adapted and validated in Brazil in 2003 ${ }^{(11)}$ in order to identify the coping strategies used in the occupational environment. OCS is a self-administrated instrument, consisting of 29 scale items using the 5 point Likert scale, in which: 1 point is "I never do it", 2 points is "I rarely do it ", 3 point "I sometimes do it", 4 points is "I often do it" and 5 point is "I always do it". These items show the way people deal with possible stressors in their work environment and compose the 3 instrumental factors, as follows: Control, composed of 11 items (1, 2, 3, $4,5,6,7,8,9,10,11)$ referent to actions and re-evaluations of a proactive cognitive character; Avoidance has 9 items $(12,13,14,15,16,17,18,19,20)$ with regards to actions and re-evaluations which suggest escapism or avoidance;
Symptoms Management has 9 items $(21,22,23,24,25$, $26,27,28,29)$ with reference to the strategies used by the individuals to manage stressful situations, including relaxation and physical activity ${ }^{(11)}$.

The data were organized and stored in an Excel Spreadsheet - Microsoft Excel 2010 - and later, electronically analyzed with the help of Statistics R, version 2.13.1.

To analyze the NSI, we calculated the average of the general population and from this average the individuals were classified as "high" and "low" stress, with values above 3 referring to high stress and below 3 low stress. Furthermore nurses were identified in the domain with the highest average, where the higher the average of the domain the higher the stress upon the professionals. To analyze the OCS, averages were calculated for each factor. In this way, the factor, which showed the highest average, was considered the factor most used by the nurses to confront stresses.

To verify the association of the domains of the NSI and the general stress using the OCS factors the Pearson Correlation Test was used. A linear regression was made between the socio-demographics, coping factors (OCS scale) and the general intensity of stress (NSI scale) in the population of this study. So, it was possible to identify which characteristics contributed to minimize or increase the stress intensity and which strategies for coping with the stress had an impact on the nurses in the hemato-oncology department. To classify the intensity of the correlations, the following classifications were used: $0<r<0,4$ (low); $0,40<r<0,60$ (moderate) e $r>0,60$ (high) $^{(12)}$. Values from $p<0,05$ were considered statistically significant. The internal consistency of the instruments were evaluated through the Cronbach Alpha Coefficient ${ }^{(13)}$.

In keeping with the guidelines of Resolution 196/96 from the National Health Council (14), in place during the data collection process of this research, the participants signed an Informed Consent Form. The research was developed together with the research group, Work, Health, Education and Nursing, following the lines of Stress, Coping and Burnout and worked within legal and ethical aspects, receiving approval by the Ethics Committee in Research of the institution under protocol number 0312.0.243.000-09.

\section{Q RESULTS}

In the internal reliability evaluation of the instruments, we observed that the Cronbach Alpha Coefficient was 0.964 for all 38 NSI items, 0.929 for the domain "Interpersonal Relationships", 0.895 for the "Intrinsic Factors at Work" and 0.859 for "Roles of Stressors within Careers". Whereas with regards 
to OCS the Alpha was 0.877 for all 29 items in the scale, 0.720 for the "Control" factor, 0.845 for the "Avoidance" and 0.776 for the "Symptoms Management". The Alpha values above were considered satisfactory to attest to the reliability of data for the nurses of the hemato-oncology unit ${ }^{(13)}$.

In this study, the nurses who performed in the hemato oncology unit obtained a stress average of $2.53 \pm 0.62$, whereas the Intrinsic Factors at Work domain 2.68 \pm 0.70 represented the highest stress to the professional of this study. As for Coping strategies, there is a prevalence of the Control factor $3.66 \pm 0.42$, which means, it is used most by the nurses when faced with stress.

Table 2, shows data with reference to non significant correlations between strategies and stress intensity.

Next is presented the dispersal between OCS factors and the intensity of general stress (figures 1,2 and 3). This analysis took place in an attempt to understand the distribution of the points obtained on the scale and to un- derstand the reason for obtaining non-correlations (points very far from the central line). In figures 1 and 2, we observe that the more the strategies of Avoidance and Control are used, the greater is the intensity of stress presented by the nurses. Although there is a buildup of points on the average line, there are points at the extremes of the Likert scale and this, far from the average, could have interfered with the results of the analysis of correlation.

Figure 3 represents the dispersal between the averages of Symptoms Management and Stress and demonstrates that the greater the use of Symptoms Management as a Coping strategy, the less is the intensity of stress presented by the professional. However, the points are dispersed and there are points away from the average line - that can justify the non-identification of correlation between the variables.

In Table 3, can be seen the linear regression model of the variables of socio demographics and professionals as a function of the intensity of stress of the nurses in this research.

Table 1 - Descriptive Measures for the NSI domain and for the OCS factors between the nurses of the hemato-oncology unit, Santa Maria, RS, Brazil, 2010.

\begin{tabular}{|c|c|c|c|}
\hline NSI/Domain & Minimum & Maximum & Average( \pm ) \\
\hline General NSI & 1.18 & 4.36 & $2.53 \pm 0.54$ \\
\hline Interpersonal Relationships & 1.18 & 3.94 & $2.42 \pm 0.65$ \\
\hline Intrinsic Factors at Work & 1.20 & 4.20 & $2.68 \pm 0.70$ \\
\hline Roles of Stressors within Careers & 1.45 & 4.36 & $2.55 \pm 0.59$ \\
\hline \multicolumn{4}{|l|}{ OCS/Factors } \\
\hline Control & 3.00 & 4.45 & $3.66 \pm 0.42$ \\
\hline Avoidance & 1.20 & 4.10 & $2.29 \pm 0.69$ \\
\hline Symptoms Management & 1.44 & 3.78 & $2.31 \pm 0.58$ \\
\hline
\end{tabular}

Source: Research Data

Table 2 - Correlation matrix between Coping factors OCS and NSI domains. Santa Maria, 2010.

\begin{tabular}{lccccc}
\multicolumn{1}{c}{ OCS Factors } & \multicolumn{1}{c}{$\begin{array}{c}\text { Interpersonal } \\
\text { Relationships }\end{array}$} & $\begin{array}{c}\text { Roles of Stressors } \\
\text { within Careers }\end{array}$ & $\begin{array}{c}\text { Intrinsic Factors } \\
\text { at Work }\end{array}$ & General Stress \\
\cline { 2 - 6 } Control & $r^{*}$ & 0.4238 & 0.3595 & 0.3927 & 0.4151 \\
\cline { 2 - 6 } & $p$ & 0.0797 & 0.1429 & 0.1069 & 0.0867 \\
\multirow{2}{*}{ Avoidance } & $r^{*}$ & 0.2232 & 0.3803 & 0.1433 & 0.2522 \\
\hline \multirow{2}{*}{ Symptoms Management } & $p$ & 0.3732 & 0.1195 & 0.5707 & 0.3128 \\
\cline { 2 - 6 } & $r^{*}$ & -0.07423 & -0.1425 & -0.1901 & -0.1306 \\
\cline { 2 - 6 } & $p$ & 0.7697 & 0.5727 & 0.4499 & 0.6053 \\
\hline
\end{tabular}

Source: Research Data

* Coefficient of Pearson Correlation 


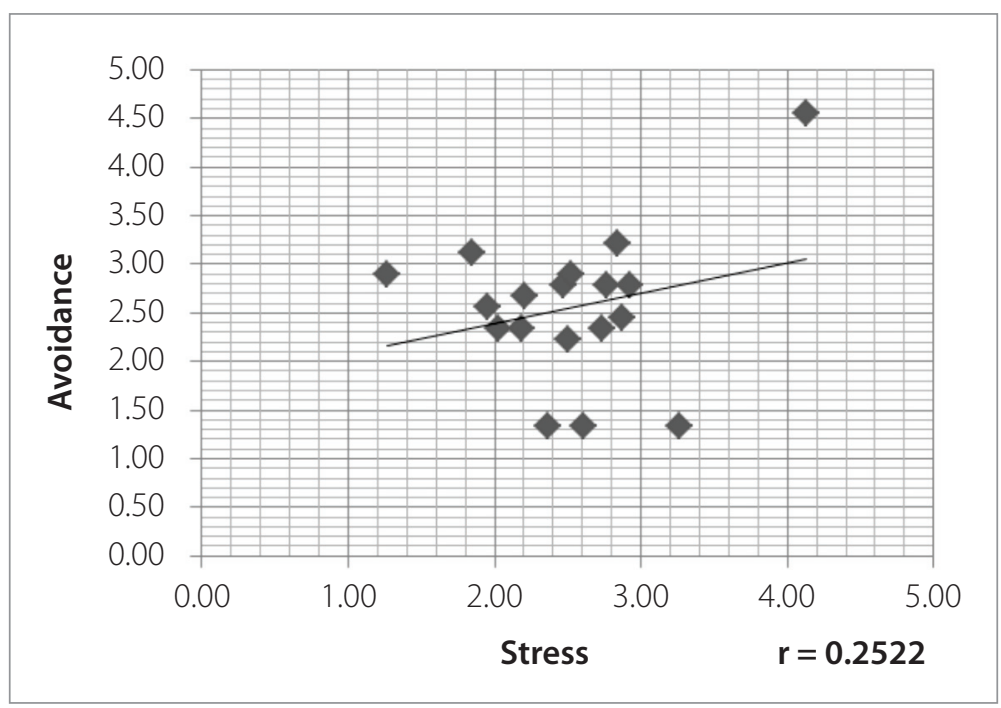

Figure 1 - Dispersal between the averages of Avoidance and Stress, Santa Maria, 2010.

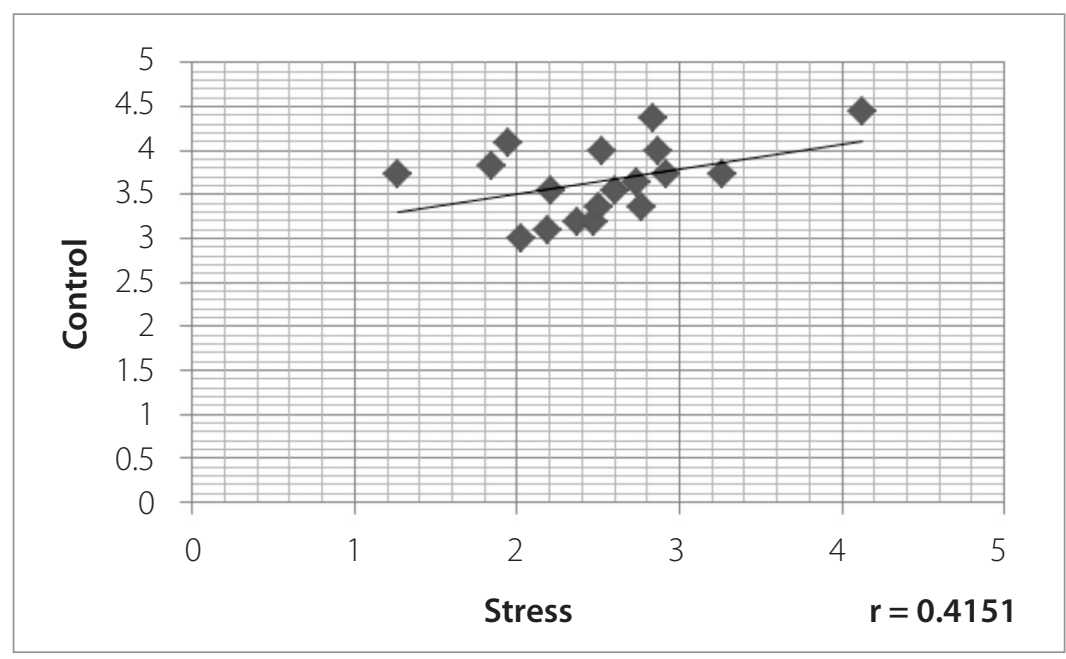

Figure 2 - Dispersal between the Averages of Control and Stress, Santa Maria, 2010.

Based on the linear regression showed in Table 2, it can be seen that the time working in the institution inversely affects the stress intensity, which is to say, the greater the time working in the institution, the less the intensity of stress. In the analysis of the qualitative variables, it's observed that having a post-graduate qualification implies a greater intensity of stress among the hemato-oncology nurses.

\section{DISCUSSION}

The results of this study show that the greater the use of the Control strategy the greater the level of stress. In the case of the coping strategies, it is important to ponder that the coping process can include as well as effectively positive responses to the stressor, also negative responses to the health of the individual. Also, we must highlight that a strategy for Coping cannot be considered as intrinsically adaptive or badly adaptive, it being necessary to consider the nature of the stressor, the availability of resources for Coping and the results of the efforts of Coping.

The selection of a control coping strategy represents a positive attitude against the stressor, an attempt to actively resolve problems related to the working environment ${ }^{(11)}$. However, in the specific context of this study, the use of this strategy indicated an elevation of stress. We believe that the peculiarities in the hemato- oncology field demand a continuous cognitive re-evaluation of a proactive 


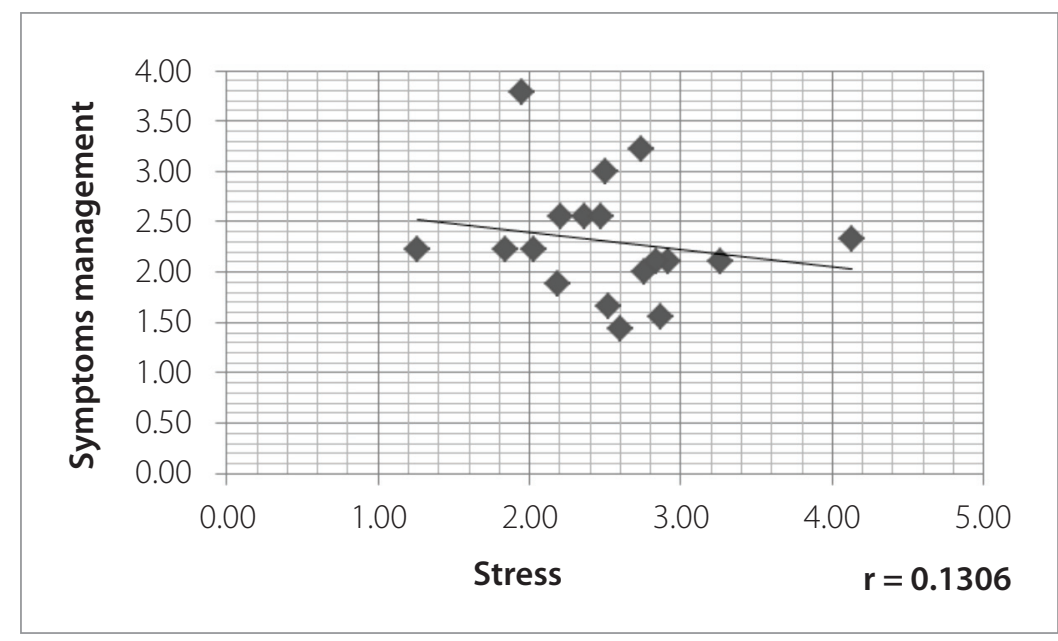

Figure 3 - Dispersal between the averages of Symptoms Management and Stress, Santa Maria, 2010.

Table 3 - Linear Regression of the variables of socio demographics and professionals as a function of the intensity of stress of the hemato-oncology nurses, Santa Maria, 2010.

\begin{tabular}{lcccc}
\multicolumn{1}{c}{ Variables } & Coefficient $\boldsymbol{\beta}$ & Standard deviation & Value t & Value $\mathbf{p}$ \\
(Intercepto) & 116.76 & 37.17 & 3.14 & 0.01 \\
Age & 2.02 & 1.15 & 1.75 & 0.11 \\
TWI ${ }^{1}$ & -3.02 & 1.25 & -2.42 & $0.04^{*}$ \\
TWU2 & -2.30 & 1.31 & -1.76 & 0.11 \\
Number of absence rates & 0.19 & 0.43 & 0.45 & 0.66 \\
Post-graduation & & & & \\
$\quad$ No & Reference & & & \\
\multicolumn{1}{r}{ Yes } & 0.82 & 26.18 & 3.14 & $0.01^{*}$ \\
\hline
\end{tabular}

Source: Research Data

${ }^{1} \mathrm{TW}=$ Time Working in the Institution

${ }^{2} \mathrm{TWU}=$ Time Working in the Unit

*Statistically significant $(p<0.05)$

character to deal with patients whose pathology presents limited perspective of cure, contributing to increased stress since the nurse feels that there is no progress in the patient's situation.

Research in France of 574 oncology nurses has shown that active strategies to resolve problems were inversely related to the number of patient deaths ${ }^{(3)}$. This result signifies that the greater the number of deaths, the less active strategies, such as control, were used by the nurses. Considering the characteristics of hemato-oncology care, which includes, chronocity, instability of the clinical presentation and emotional repercussions involved, makes it more difficult for the nurse to be pro-active. In this way, there are repercussions related to the increased stress due to the reduction of effective resolution options for the problems, since there is not the possibility of a cure for many types of cancer.

So, to face conditions that are not passive to effective resolution, the Control strategy, in this specific context, wasn't considered adequate by the nurses as a way to cope, because when it used it only contributed to an increase in occupational stress.

The Avoidance strategy, related to actions and re-evaluations, suggests escapism and avoidance, also contributed to an increase of the nurses' stress. Because it is focused on the emotion, a person uses this type of strategy so as to alter their understanding of the stressor and to reduce the bad feeling evoked or even to avoid the stressor. 
The systematic and exclusive use of this strategy can push the nurse away from the reality they need to face every day, besides, it does not allow for the use of more active resolution strategies ${ }^{(1)}$. It should be highlighted that it is not always possible to avoid occupational stresses, because they are intrinsic in the working process of the oncology nurse. Soon, trying to avoid the reality in which one is inserted into, will contribute to an increase of intensity of occupational stress among these professionals.

Along these lines, in a Portuguese study with 96 nurses it was noted that there was a significant negative correlation between general health and the coping strategy of avoidance ${ }^{(1)}$. For the authors, this result emphasizes the idea that focus strategies based on the removal of the person from the stressors can protect the individuals in oneoff crises or in situations with no possibility of resolution - but they are not facilitators of physical and emotional balance in long term situations and they require active participation of the individual.

In another study we observed the use of escapism avoidance of $37 \%$ of the active nurses in pediatrics oncology and it signaled that these professionals still feel difficulties with confronting death or the possibility of it ${ }^{(15)}$. For the researchers, the escape-avoidance behavior is a way to fantasize about possible solutions to the problem without, however, taking any attitudes towards changing them. Still, avoidance is considered a conscious strategy of the reality of the threat, characterized as an attempt to normalize the emotional impact of the stress on the individual, and because of this, they become less adaptive than those focused on the problem.

Already, the option for the Symptoms Management strategy has had a positive effect on occupational stress, which means that the use of this strategy gives benefits when dealing with occupational stress in this context. Considered a strategy with very little resolution, due to its emotional content, it refers to actions commonly reported as strategies used by individuals to deal with stressful situations - including relaxation or physical activity ${ }^{(11,16)}$. In an Australian research made with 32 nurses, social networks, the common room for the hospital staff, exercise, family activities, household activities and sleep were identified as the principle strategies for coping with stress (17). In this case, for the users of the instrument used here, even though there is a greater propensity for strategies of control, which are associated with lower intensities of stress, in very stressful environments, strategies of avoidance and symptoms management, can be more adaptable. They also highlight that in insalubrious environments and with an overload of work - such as in the hemato-oncology environment - strategies focusing on emotion can be more often used but not necessarily be more effective ${ }^{(11)}$.

In this context, the complementarily of a selected strategy is advocated for when the situation is considered highly exhausting ${ }^{(8)}$. Therefore, the results of this study confirm that there isn't just one effective coping strategy, because the option of different strategies depends on the individual, who can act in different ways when faced by the same stressor. So, the characteristics of each professional, the personal resources available to them and the specific context of their work must be respected.

As to the repercussions with regards to having a post-graduate qualification and of having less time working in the health Institution in relation to the stress intensity of the hemato-oncology units, these variables refer to conditions, which are part of the nurses professional journey and influence their abilities with coping strategies, as mentioned in this study. In this way, when analyzing hospital nurses, researchers pointed out the need for time and recognition, the importance of academic training (use of palliative care, pain and support control), patient and family support are characteristics which impact noticeably on the stress perceived in hemato-oncology professionals (3).

In this way, the performance of these units demands theoretical and practical understanding, the development of skills which can guide their professional performance, taking into consideration the patients physical, emotional, social and spiritual dimensions, and their contact with chronic illness - which is unpredictable and continuous in its demands. In oncology, the search for a specialization course is important to supplement the lack of studies in cancerology in the majority of Nursing courses.

The context of work in oncology and some characteristics of the nurses impact on the intensity of stress on these professionals who seek to minimize the effects of the stress, mainly, by passive actions to cope with the stressors - those ones which make up the Symptoms Management strategies.

\section{- CONCLUSIONS}

A significant correlation between coping strategies and the stress intensity of the nurses who work in hemato-oncology was not verified in this report. In the dispersal analysis, we verified that Control and Avoidance imply greater stress intensity, whereas Symptom Management was effective in reducing the stress in hemato-oncology.

The results in this study show the benefit of Symptom Management strategy with focused on emotion, to deal with the occupational stress in hemato-oncology nurses. 
Taking into consideration the characteristics and specifics in hemato-oncology care, the coping efforts of the individuals through active conducts of control (strategies focused on the problem) imply the wearing down of the professionals involved due to the therapeutic restrictions in oncology.

It shows that this alternation between the reduced possibility of controlling events and the necessity to submit to the everyday circumstances in hemato-oncology can create a change in attitude and the adoption of different strategies to confront diverse situations in the working environment. This can justify the use of Coping strategies simultaneously and combined, as well as the variability of the effects on the occupational stress. And so, even with distinct closures, two types of coping can be used, confirming the interdependence and complementary character of two functional categories of coping, a condition supported by different studies on this theme.

The limitation in this study was the reduced number of professionals taking part, a fact that could have influenced the data variables, and consequently, the correlation results. Furthermore, the limited number of studies involving the delineation utilized for the constructs analyzed here made it difficult to approximate the results with other national and international studies.

The results obtained could contribute to the understanding of occupational stressors in oncology nursing, for the development of actions which anticipate adverse reactions to the nursing professional's health and well-being, and consequently, for the promotion of quality nursing care for the patients.

\section{口 REFERENCES}

1. Gomes SFS, Santos MMMMCC, Carolino ETMA. Riscos psicossociais no trabalho: estresse e estratégias de Coping em enfermeiros em oncologia. Rev Latino-Am Enferm [Internet]. 2013[cited 2013 dec 13];21(6):1282-9. C: http://www.revistas.usp.br/rlae/article/view/76051/79740

2. Pinto MH, Cruz MF, Cesarino CB, Pereira APS, Ribeiro RCHM, Beccaria LM. 0 cuidado de enfermagem ao paciente oncológico fora de possibilidade de cura: percepção de um grupo de profissionais. Cogitare Enferm [Internet]. 2011[cited 2013 oct 12];16(4):647-53. Available in: http://ojs.c3sl.ufpr.br/ojs2/index.php/ cogitare/article/view/25433/17052

3. Pronost AM, Le Gouge A, Leboul D, Gardembas-Pain M, Berthou C, Giraudeau B. Relationships between the characteristics of oncohematology services provi-

\section{Author's address:}

Laura de Azevedo Guido

Av. Roraima, 1000, sala 1302, prédio 26, Camobi

97105-900, Santa Maria, RS

E-mail: Iguido344@gmail.com ding palliative care and the sociodemographic characteristics of caregivers using health indicators: social support, perceived stress, coping strategies, and quality of work life. Support Care Cancer. 2012;20(3):607-14

4. Giansante M, Ballarini V. Perceived stress and coping strategies in medical and nursing staff in a department of clinical hematology: pilot study. G Ital Med Lav Ergon. 2012;34(2 Suppl B):B23-8.

5. Paschoal T, Tamayo A. Validation of the work stress scale. Estud Psicol (Campinas) [Internet]. 2004[cited 2013 oct 12];9(1):45-52. Available in: http://www. scielo.br/pdf/epsic/v9n1/22380.pdf

6. Stacciarini JMR, Tróccoli BT. An instrument to measure occupational stress: a nurses' stress inventory. Rev latinoam enferm[Internet]. 2000[cited 2013 0ct 13];8(6):40-9.Available in: http://www.scielo.br/pdf/rlae/v8n6/12347.pdf

7. Umann J, Silva RM, Benetti ERR, Guido LA. Stress and coping among nurses of hemato-oncologic units. Rev Rene[Internet]. 2013[cited 2013 nov 22];14(4):783-90. Available in: http://www.revistarene.ufc.br/revista/index. php/revista/article/viewFile/1212/pdf

8. Lazarus RS, Folkman S. Stress, appraisal and coping. New York: Springer Publishing Company; 1984.

9. Guido LA, Silva RM, Goulart CT, Kleinübing RE, Umann J. Stress and coping among surgical unit nurses of a teaching hospital. Rev Rene [Internet]. 2012 [cited 2013 nov 22];13(2):428-36. Available in: http://www.revistarene.ufc.br/ revista/index.php/revista/article/view/226/pdf

10. Kleinubing RE, Goulart CT, Silva RM, Umann J, Guido LA. Stress and coping in nurses of adult and cardiological intensive care. Rev Enferm UFSM [Internet]. 2013[cited 2013 set 22];3(2):335-44. Available in: http://cascavel.ufsm.br/ revistas/ojs-2.2.2/index.php/reufsm/article/view/8924/pdf

11. Pinheiro FA, Tróccoli BT, Tamayo MR. Coping measurement in occupational setting. Psicol Teor Pesqui [Internet]. 2003[cited 2013 set 22];19(2):153-8. Availdble in: http://www.scielo.br/pdf/ptp/v19n2/a07v19n2.pdf

12. Bisquerra R, Sarriera JC, Martínez F. Introdução à estatística: enfoque informático com o pacote estatístico SPSS. Porto Alegre: Artmed; 2004.

13. Field A. Descobrindo a estatística usando o SPSS. 2. ed. Porto Alegre: Artmed; 2009.

14. Conselho Nacional de Saúde (BR). Resolução no 196, de 10 de outubro de 1996. Dispõe sobre diretrizes e normas regulamentadoras de pesquisas envolvendo seres humanos. Bioética. 1996;4(2 Supl):15-25.

15. Lages MGG, Costa MAO, Lopes TR, Amorim FCS, Neto APA, Nascimento IRD. Coping strategies of nurses toward patients in pediatric oncology. Rev Bras Cancerol [Internet]. 2011[cited 2013 nov 11];57(4):503-10. Available in: http:// www.inca.gov.br/rbc/n_57/v04/pdf/06_artigo_estrategias_enfrentamento_enfermeiros_frente_paciente_oncologico_pediatrico.pdf

16. Umann J. Estresse, coping e presenteísmo em enfermeiros hospitalares [dissertação]. Santa Maria (RS): Programa de Pós-Graduação em Enfermagem, Universidade Federal de Santa Maria; 2011.

17. Happell B, Reid-Searl K, Dwyer T, Caperchione CM, Gaskin CJ, Burke KJ. How nurses cope with occupational stress outside their workplaces. Collegian. 2013;20(3):195-9.

Received: 16.01.2014

Approved: 08.08.2014 